\title{
O ESCRAVO NO BRASIL NA PASSAGEM DO SÉCULO XVIII PARA O SÉCULO XIX: CONSIDERAÇÕES A PARTIR DAS AMBIVALÊNCIAS DO COMPADRIO DE CATIVOS NA REGIÃO DO PARANÁ
}

\author{
Helena Schiessl Cardoso*
}

SUMÁRIO: 1. INTRODUÇÃO. 2. UM POSSÍVEL SIGNIFICADO DO COMPADRIO: O ESTABELECIMENTO DE REDES DE PODER ATRAVÉS DO PARENTESCO ESPIRITUAL. 3. O COMPADRIO DE ESCRAVOS NO BRASIL: ALGUMAS QUESTÕES LEVANTADAS PELA HISTORIOGRAFIA RECENTE. 3.1. PADRÕES DE ESCOLHA DOS PADRINHOS: RELAÇÕES VERTICAIS OU RELAÇÕES HORIZONTAIS?. 3.2. DESCARTANDO A HIPÓTESE DO PATERNALISMO NA RELAÇÃO ENTRE SENHOR E ESCRAVO?. 3.3. SIGNIFICADO AMBIVALENTE DO COMPADRIO: SOLIDARIEDADE OU DOMINAÇÃO?. 4. ALGUNS ESTUDOS DE CASOS: O COMPADRIO NA REGIÃO DO PARANÁ NA PASSAGEM DO SÉCULO XVIII PARA O XIX. 4.1. SÃo José dos Pinhais. 4.2. Curitiba. 5. ConsideraÇÕES Finais. 6. REFERÊNCIAS.

\section{RESUMO}

As relações de compadrio de escravos revelam aspectos importantes sobre o cativo no Brasil dos séculos XVIII e XIX. Tendo em vista que este instituto permite compreender o funcionamento das relações políticas e sociais daquela época, pretendese refletir a condição do escravo, em especial a partir das ambivalências destas relações de parentesco fictício. Para tanto, é necessário apontar inicialmente para algumas tendências enunciadas pela historiografia recente, sem contudo esquecer de verificar a sua validade para um espaço geográfico determinado - neste trabalho a região atualmente compreendida pelo Estado do Paraná. Tal análise permite inferir que a condição do escravo não pode ser deduzida simplesmente de sua classificação jurídica como "bem semovente". Os cativos, aparentemente, não eram meros objetos de dominação, mas exerciam também um papel ativo na sociedade. Deste modo, desenha-se a hipótese paradoxal de que a atitude dos escravos pode ter contribuído, em certa medida, à manutenção do sistema jurídico-político da escravidão por mais de três séculos.

Palavras-chave: Compadrio; Economia política de favores; Escravo; Escravidão; Paraná.

* Mestranda do programa de pós-graduação da UFPR, área de concentração "Direito do Estado", linha de pesquisa "Direito, Poder e Controle". E-mail: helena_2884@yahoo.com.br 


\section{INTRODUÇÃO}

Nas pesquisas historiográficas recentes sobre a escravidão, é notável um despertar para a temática das relações de compadrio de escravos. Houve nas últimas duas décadas um grande esforço de alguns historiadores no sentido de desvendar as dinâmicas do apadrinhamento de cativos no Brasil colonial a partir da análise, sobretudo, de registros paroquiais de batismo.

Debruçar-se sobre esta temática é de grande interesse porque pode quebrar certos mitos difundidos pela historiografia "tradicional" - incluindo-se aqui também a história do direito - e revelar aspectos importantes, e ainda desconhecidos, sobre o funcionamento das relações políticas e sociais da época, principalmente quando envolvem a figura do escravo, ao se tratar de uma temática que ainda requer aprofundamento de estudos no Brasil. ${ }^{1}$

As pesquisas já realizadas apontam para algumas tendências que, em seguida, deverão ser apresentadas. No entanto, tendo em vista a amplitude do espaço geográfico e as diversidades regionais, impõe-se certo cuidado metodológico em relação a afirmações genéricas, a fim de não incorrer em equívocos tão comuns a estudos que ignoram as informações contidas nas fontes primárias, que, direta ou indiretamente, podem permitir inferências sobre a realidade social de seu tempo.

Inserido neste contexto, o presente trabalho se destina a refletir a condição do escravo no Brasil dos séculos XVIII e XIX a partir das ambivalências do compadrio de cativos indicadas pela historiografia recente - em parte muito preocupada com uma

${ }^{1}$ Neste contexto, cabe lembrar que, por muito tempo, pensava-se que na senzala vigia a anomia e a promiscuidade, bem como era difundida a ideia de que não tenham existido famílias escravas por causa de sua inviabilidade econômica. No entanto, a partir de novas fontes, foi possível à historiografia mais recente conhecer melhor a realidade do cativeiro, e hoje a existência de famílias escravas já é tema mais do que superado. (FLORENTINO, Manolo; GÓES, José Roberto. A paz das senzalas: famílias escravas e tráfico atlântico. Rio de Janeiro: Civilização Brasileira, 1997, p. 27-28.) Mesmo assim, ainda há muita fonte documental a ser explorada para compreender melhor a condição dos escravos e da instituição da escravidão no Brasil. 
verdadeira "pesquisa de campo" e sem receio de aventurar-se na trabalhosa busca e decodificação de fontes documentais de tempos passados -, com um especial enfoque para alguns estudos de casos realizados na região atualmente conhecida como o Estado do Paraná.

O propósito subjacente a esta reflexão é verificar se a condição de escravo poderá ou não ser esgotada pela sua classificação jurídica como "bem semovente" até que ponto haveria ou não alguma contribuição por parte dos cativos na manutenção de um sistema jurídico-político que diferenciava entre escravos e pessoas livres.

\section{UM POSSÍVEL SIGNIFICADO DO COMPADRIO: O ESTABELECIMENTO DE REDES DE PODER ATRAVÉS DO PARENTESCO ESPIRITUAL}

O batismo é o primeiro sacramento da Igreja Católica e, como rito de passagem que representa, indica a iniciação do batizando na comunidade cristã, bem como a sua salvação do pecado original. São estabelecidos, na pia batismal, novos laços de parentesco, de natureza espiritual, que unem os pais do batizando aos padrinhos, através da relação do compadrio, destinada a produzir solidariedade recíproca. ${ }^{3}$ Neste ato religioso, os padrinhos assumem diversas responsabilidades perante o afilhado, sobretudo o compromisso de zelar pela sua educação espiritual, ao passo que cabe ao batizando o dever de obediência, fidelidade e reverência. ${ }^{4}$

Cabe ressaltar, sobretudo para o propósito deste artigo, que batismo e compadrio, além do evidente significado religioso, carregavam também um

${ }^{2}$ GRINBERG, Keila. Código Civil e cidadania. Rio de Janeiro: Jorge Zahar, 2001, p. 53.

${ }^{3}$ GUDEMAN, Stephen; SCHWARTZ, Stuart. Purgando o pecado original: compadrio e batismo de escravos na Bahia no século XVIII. In: REIS, João José (org). Escravidão e invenção da liberdade: estudos sobre o negro no Brasil. São Paulo: Brasiliense, 1988. p. 41.

${ }^{4}$ VENÂNCIO, Renato Pinto; SOUZA, Maria José Ferro de; PEREIRA, Maria Teresa Gonçalves. O compadre Governador: redes de compadrio em Vila Rica de fins do século XVIII. Revista Brasileira de História, v. 26, p. 273-294, 2006. 
significado social, cultural, econômico e político.

Já a mera leitura dos registros paroquiais de batismo da época colonial permite corroborar tal afirmação, pois estes documentos contêm informações que ultrapassam as exigências eclesiásticas e tendem a classificar a "persona social total" das pessoas envolvidas no batismo. ${ }^{5}$ A função de identificação pessoal e social dos registros justifica-se, entre outros, pelo fato que, até o advento da República, não existia registro civil de batismo. ${ }^{6}$ Deste modo, a função hoje exercida pela certidão de nascimento cumpria-se na época através dos registros eclesiásticos, que continham geralmente, mas nem sempre de modo completo, o nome da igreja, a data do batismo e do nascimento do batizando, o seu nome e sua legitimidade, sua condição social e cor, o nome de seus pais e padrinhos, o nome do senhor (caso envolvesse escravos), e suas respectivas condições sociais. ${ }^{7}$

Estudos mais aprofundados, realizados pela historiografia mais recente, com base nestas fontes documentais, indicam que a própria escolha dos padrinhos reflete o sentido social e político do compadrio e possibilitam conhecer as formas de sociabilidade das pessoas daquela época.

A literatura indica a forte tendência dos pais de procurar apadrinhar seus filhos por pessoas de estatus social superior ao deles, na expectativa de receber proteção de natureza material e imaterial dos padrinhos, e como tentativa de inserção e ascensão social de sua própria família. Quando os pais não buscavam padrinhos de condição social superior, ao menos convidavam pessoas de estatus social igual, contudo nunca inferior. Este padrão de escolha superava, em muito, os critérios de seleção dos padrinhos exigidos pela igreja, ${ }^{8}$ o que manifesta claramente o sentido que vai além do

\footnotetext{
${ }^{5}$ GUDEMAN; SCHWARTZ, op. cit., p. 39.

${ }^{6}$ GRINBERG, K., op. cit., p. 52.

${ }^{7}$ VENÂNCIO; SOUZA; PEREIRA, op. cit.

${ }^{8}$ Segundo as Constituições Primeiras do Arcebispado da Bahia de 1707, os pais deveriam escolher um padrinho, de no mínimo 14 anos, e uma madrinha, de no mínimo 12 anos para a criança, devendo os padrinhos, eles mesmos, já terem sido batizados. Estariam impedidos ao exercício desta função, os próprios pais, os infiéis, hereges ou públicos excomungados, os interditos, surdos ou mudos, os que ignoram os princípios da Santa Fé, e os religiosos, com exceção daqueles que
} 
religioso.

Desta forma, na hipótese de padrinhos de maior hierarquia social, ainda que em teoria - o compadrio nivelava os pais e padrinhos através do parentesco fictício, na verdade, por envolver muitas vezes pessoas desiguais do ponto de vista de sua condição social, tais laços manifestavam, além do elemento da solidariedade, na opinião de Silvia Maria Jardim Brügger, um componente de dominação, não só em face do afilhado, que devia respeito aos padrinhos, mas também perante toda a sua unidade familiar. Representa o compadrio, portanto, elemento fundamental na construção de redes de poder naquela sociedade. ${ }^{9}$

Neste sentido, bem no espírito das relações de reciprocidade típicas de uma sociedade de Antigo Regime, ${ }^{10}$ diversos autores apontam para uma "economia política

pertenciam às ordens militares. (Compare neste sentido, QUIRINO, Gisele Dias. Compadres e comadres: um estudo sobre o prestigio social dos parentes rituais (Porto Feliz, São Paulo, século XIX). In: XIII ENCONTRO DE HISTÓRIA ANPUH-RIO IDENTIDADES, 2008, Seropédica. Anais do XIII Encontro de História Anpuh-Rio Identidades, 2008. Disponível em: http://encontro2008.rj.anpuh.org/resources/content/anais/1212946675_ARQUIVO_textogisele.pdf. Acesso em: 03 ago. 2009).

${ }^{9}$ BRÜGGER, Silvia Maria Jardim. Compadrio e escravidão: uma análise do apadrinhamento de cativos em São João Del Rei, 1730-1850. In: XIV ENCONTRO NACIONAL DE ESTUDOS POPULACIONAIS, 2004, Caxambú. Anais do XIV Encontro Nacional de Estudos Populacionais. Caxambu: ABEP, 2004. Disponível em: http://www.abep.nepo.unicamp.br/site_eventos_abep/PDF/ABEP2004_119.pdf. Acesso em: 03 ago. 2009, p. 18.

${ }^{10}$ A historiografia contemporânea indica que a sociedade na América Portuguesa se fundava sob princípios de reciprocidade, que "seriam responsáveis pela organização de uma cadeia de relacionamentos que, ao mesmo tempo, tecia coesões sociais horizontais e verticais fundadas em obrigações mútuas, mas diferenciadas, delineando planos hierarquicamente ordenados. Tal cadeia partiria da base local, onde se concretizava a vivência cotidiana [...] abrindo-se, escalonadamente, a outros níveis de pertencimento, que ao fim sedimentava uma relação de vassalagem à soberania lusitana." (ANDREAZZA, Maria Luiza. Dominium, terras e vassalagem na América Portuguesa. In: SILVA, Luiz Geraldo (org.). Facetas do Império na História: conceitos e métodos. São Paulo: Hucitec, 2008. p. 283) É de se notar que, ao nível local, as hierarquias se estruturavam em especial em torno da família colonial. Trata-se na verdade da transposição de uma economia política dos privilégios, institucionalizada pelas monarquias européias do Antigo Regime, que significava um pacto recíproco entre monarca e súdito: "[...] o indivíduo ou o grupo que, em troca de serviços prestados (mormente na conquista e colonização do ultramar), requeria uma mercê, um privilégio ou um cargo ao rei, reafirmava a obediência devida [...] o monarca reconhecia o simples colono como vassalo, reforçando o sentimento de pertença e estreitando os laços de sujeição em relação ao reino e à monarquia, reafirmando o pacto político sobre o qual se forjava a soberania portuguesa nos quatro cantos do mundo." (BICALHO, Maria Fernanda Baptista. As câmaras ultramarinas e o governo do Império. In: FRAGOSO, João (org.). $\mathbf{O}$ antigo regime nos trópicos: a dinâmica imperial portuguesa 
de favores" praticada através do instituto do batismo e das relações de compadrio.

Em estudo que se dedica às relações políticas e sociais formadas através do apadrinhamento entre os membros da elite de Vila Rica, no período de 1777 até 1789 , Renato Pinto Venâncio, Maria José Ferro de Souza e Maria Teresa Gonçalves Pereira sugerem, com base na análise da trajetória de quatro membros da elite, que apadrinhavam pessoas de condição social inferior, a evidência de uma economia de dom e contradom naquela região. Demonstram, em seu trabalho, que as relações de compadrio implicavam a concessão de benefícios, de um lado, e fidelidade, do outro. Para os autores,

a noção de 'amizade desigual' [...] tornava-se o elemento legitimador das relações de poder internas ou externas aos grupos sociais. No caso do compadrio, tais vínculos eram ainda mais intensos, pois geravam laços de parentesco para o resto da vida - tanto na relação padrinho-afilhado quanto na compadre-compadre. Nesse sentido, é possível afirmar que o compadrio consistia em um dos elementos de estruturação das redes sociais que organizavam a vida cotidiana. ${ }^{11}$

Em relação às redes de compadrio, destacam ainda que as práticas de batismo geravam uma "rede política e social que podia começar entre humildes ex-escravas e terminar em famílias reais européias."12

Outro fator, que se pode extrair de sua pesquisa, em favor da significação social e política do compadrio, é o fato que os personagens da elite investigados eram chamados a apadrinhar um número muito grande de crianças. É interessante ressaltar também que muitas vezes os compadres em potencial nem conheciam as crianças a serem batizadas, ou seja, não se tratava de relações nascidas do convívio social, sendo o convite frequentemente feito por correspondência e fazendo-se representar o

(séculos XVI-XVIII). Rio de Janeiro: Civilização Brasileira, 2001. p. 219).

${ }^{11}$ VENÂNCIO; SOUZA; PEREIRA, op. cit.

${ }^{12}$ Ibidem, loc. cit. 
padrinho por procuração no ato do batismo. ${ }^{13}$

É nesta direção que aponta também o estudo de Martha Daisson Hameister, sobre os registros de batismo dos filhos de açorianos estabelecidos na Vila do Rio Grande, no espaço temporal entre 1738 a 1763. Igualmente constatou que havia determinadas pessoas que eram chamadas com muita frequência para assumir o compromisso junto à pia batismal, ainda que não tivessem nenhum vínculo com as crianças. Tratava-se, no entanto, de pessoas que eram ligadas a famílias que se destacavam na região por seus bens materiais ou seu poder simbólico.

Verifica-se novamente o estabelecimento de um mecanismo de trocas através do compadrio, nomeadamente entre desiguais. Os mais pobres tentavam se inserir nas famílias de maior prestígio e buscavam proteção e favores, principalmente em vistas ao futuro do afilhado e de sua família. Por outro lado, os padrinhos de estatus social melhor buscavam incrementar seu prestígio e poder através do apoio das e a ingerência sobre as famílias que se encontravam sob sua proteção. O ciclo de troca se estabelecia então da seguinte forma, segundo a autora:

convida-se para padrinho de um filho alguém que possa dar-lhe a devida proteção e auxílio; dá-se auxílio e proteção a um afilhado e aos compadres, pois a existência destes demonstra a capacidade de manter uma parcela da população sob cuidado e influência. Eis o que a porção superior desta relação de troca entre desiguais tem a ganhar nestes parentescos forjados à pia batismal. ${ }^{14}$

Quer dizer, nem os pobres não eram tão pobres que não tinham nada a oferecer, nem os ricos tão ricos que não precisavam receber nada. ${ }^{15}$ São estas, então, as redes de reciprocidade que caracterizavam o estabelecimento de alianças através do

${ }^{13}$ Ibidem, loc. cit.

${ }^{14}$ HAMEISTER, Martha Daisson. Na pia batismal: estratégias de interação, inserção e exclusão social entre os migrantes açorianos e a população estabelecida na vila de Rio Grande, através do estudo das relações de compadrio e parentescos fictícios (1738-1763). In: V CONGRESSO BRASILEIRO DE HISTÓRIA ECONÔMICA E $6^{\mathrm{a}}$ CONFERÊNCIA INTERNACIONAL DE HISTÓRIA DE EMPRESAS - 10 anos de ABPHE, 2003. Disponível em: http://www.abphe.org.br/congresso2003/Textos/Abphe_2003_91.pdf. Acesso em: 03 ago. 2009.

${ }^{15}$ Ibidem, loc. cit. 
parentesco espiritual, que traziam benefícios a ambos os pólos da relação e evidenciam aspectos sociais e políticos da população da América Portuguesa.

\section{O COMPADRIO DE ESCRAVOS NO BRASIL: ALGUMAS QUESTÕES LEVANTADAS PELA HISTORIOGRAFIA RECENTE}

No estudo sobre o compadrio de cativos destacam-se, na historiografia recente, os trabalhos de Stephen Gudeman e Stuart Schwartz, de um lado, e de Manolo

Florentino e José Roberto Góes, do outro. É a partir de suas pesquisas, baseadas sobretudo em fontes primárias, isto é, os assentos de batismo, que foram levantadas algumas questões centrais, a partir das quais se debate hoje a temática do compadrio de cativos e a própria condição do escravo na sociedade da América Portuguesa dos séculos XVIII e XIX.

\subsection{PADRÕES DE ESCOLHA DOS PADRINHOS: RELAÇÕES VERTICAIS OU RELAÇÕES HORIZONTAIS?}

As pesquisas empreendidas por Stephen Gudeman e Stuart Schwartz, sobre o compadrio na Bahia no século XVIII, tiveram como escopo iluminar a relação entre senhor e escravo, bem como o contexto sócio-político da sociedade colonial marcada pelo escravismo. Para levar a efeito o estudo proposto, os autores consultaram principalmente os registros paroquiais do Recôncavo baiano da década de 1780, tendo em vista a escassez de informação direta sobre a dinâmica e o significado do compadrio no Brasil colonial, bem como a impossibilidade de assumir as regulamentações eclesiásticas da arquidiocese baiana como espelho da realidade social, já que muitas vezes a prática era diferente da prescrição legal. Sobre a região 
explorada, cabe destacar que, naquela época, caracterizava-se por ser uma zona de engenho, destinada ao cultivo da cana de açúcar e ao processamento do açúcar para exportação, onde o trabalho escravo era muito importante para o processo produtivo. ${ }^{16}$

No que diz respeito aos padrões de escolha dos padrinhos para aquela localidade, os autores identificaram que os escravos eram batizados tanto por escravos quanto por livres, enquanto os filhos nascidos livres quase sempre recebiam padrinhos livres. Os dados colhidos demonstram que em $70 \%$ dos batismos de escravos optavase por padrinhos livres, em $20 \%$ dos batismos de cativos a escolha dos padrinhos recaía em escravos, e, por fim, em $10 \%$ dos batismos de escravos a eleição era de padrinhos libertos. ${ }^{17}$ É notável que, para todo o espaço temporal explorado, não se verificou nenhum batismo pelo próprio senhor da criança escrava. ${ }^{18}$

Estes números sugerem que, também entre os escravos, valia o imperativo social de escolher os padrinhos de estatus social igual ou superior ao apadrinhado ainda que fossem de estatus social inferior ao do próprio senhor. Além da hierarquia social dos padrinhos, interferia na escolha do padrinho, entre outros, ainda a sua cor, pois a tendência era optar por padrinhos com cor de pele igual ou mais clara. ${ }^{19}$

Tais constatações apontam novamente para o significado social e político das relações de compadrio, pois "a escolha de padrinhos na Bahia era quase sempre verticalmente ascendente ou horizontal, nunca descendente. O que definia o direcionamento social era o contexto da escravidão e a cor."20

Aponta, por conseguinte, a análise levada a efeito pelos autores para uma tendência que indica a preponderância do estabelecimento de relações verticais no compadrio de escravos, isto é, laços entre pólos hierarquicamente desiguais na escala social.

\footnotetext{
${ }^{16}$ GUDEMAN; SCHWARTZ, op. cit. p. 34-37.

${ }^{17}$ Ibidem, p. 46-47.

${ }^{18}$ Ibidem, p. 40.

${ }^{19}$ Ibidem, p. 48.

${ }^{20}$ Ibidem, p. 50.
} 
Em oposição a esta conclusão, posiciona-se o trabalho posterior de Manolo Florentino e José Roberto Góes. Estes historiadores identificaram em suas pesquisas a preponderância de interrelações entre escravos através do compadrio, ou seja, perceberam, através das fontes garimpadas, a preponderância de laços horizontais e não verticais nas escolhas dos padrinhos de cativos, ou seja, havia maior número de vínculos estabelecidos entre pessoas de mesmo nível social.

Os dados levantados para o agro fluminense indicam, para a freguesia de Inhaúma, para o espaço temporal de 1817 a 1842, que dois terços dos padrinhos das crianças cativas eram escravos. Dentre estes, igualmente dois terços eram propriedade do mesmo senhor, ou seja, eram provavelmente companheiros de cativeiro. Estes padrões se encontram também na freguesia de Jacarepaguá, para o período de 1795 a 1805, e em Mambucaba, entre 1830 e $1849 .^{21}$

Com base nestes trabalhos paradigmáticos, os trabalhos historiográficos posteriores tentam identificar a preponderância dos eixos vertical ou horizontal, ou sua concomitância, nos laços de parentesco espiritual de cativos.

\subsection{DESCARTANDO A HIPÓTESE DO PATERNALISMO NA RELAÇÃO ENTRE SENHOR E ESCRAVO?}

Uma das grandes contribuições do trabalho de Stephen Gudeman e Stuart Schwartz diz respeito ao questionamento da tese de diversos autores, que afirmavam a existência de um mecanismo de reforço da relação entre senhor e escravo através das relações de compadrio. Ao analisar os registros paroquiais de batismo do Recôncavo baiano, os autores descobriram, como já explicitado, que na região estudada, apesar da tendência de buscar pessoas de condição social superior para apadrinhar os filhos de cativos, não houve nenhum senhor que tivesse funcionado como padrinho de seu

\footnotetext{
${ }^{21}$ FLORENTINO; GÓES, op. cit., p. 92.
} 
escravo. $^{22}$ Não estaria este fato contrariando a tese do paternalismo projetado através do compadrio entre senhor e escravo?

Bem, em primeiro lugar, na opinião dos autores, tal padrão de escolha, que parece ter sido difundido para além do Recôncavo baiano, poderia se justificar pelo antagonismo extremo entre as instituições da igreja e da escravidão. Na perspectiva eclesiástica, o compadrio estabelecia uma relação espiritual de proteção, representava associação ou solidariedade entre as pessoas que se comprometiam na pia batismal. $\mathrm{O}$ batizado do escravo significaria o seu reconhecimento como igualmente cristão e sua libertação do pecado original, bem como lhe atribuiria, de certa forma, o atributo da humanidade. Diametralmente oposta estava a lógica de dominação típica da sociedade escravista da época, pois os escravos eram vistos como propriedade viva de seus senhores. Desta forma, os atributos implícitos no batizado estariam em evidente contradição à lógica escravista, pelo que o batismo de escravos se projetava como perigoso para a instituição da escravidão. ${ }^{23}$

Diante desta incompatibilidade de idiomas, os autores sugerem, a partir dos dados coletados, que a prática social era então separar estas duas esferas conflitantes: ou seja, procedia-se ao batizado dos escravos em consequência da pressão eclesiástica; no entanto, o padrinho deveria ser outra pessoa que o senhor do escravo, fosse ela escrava, livre, liberta ou senhor de outro cativo. ${ }^{24}$ Ou seja, nas palavras de Stuart Schwartz:

O batismo, por representar igualdade, humanidade e libertação do pecado, simbolizava qualidades incompatíveis com a condição de escravo e apresentava uma contradição potencial que era resolvida não com a abolição da escravidão ou do batismo, mas com a manutenção em separado desses elementos conflitantes. O renascimento do cativo através do batismo não se dava por intermédio de seu próprio senhor. Outros escravos, livres ou proprietários de outros cativos, serviam-

\footnotetext{
${ }^{22}$ GUDEMAN; SCHWARTZ, op. cit., p. 40.

${ }^{23}$ Ibidem, p. 41-43.

${ }^{24}$ Ibidem, p. 43.
} 
lhe de padrinho. ${ }^{25}$

A conclusão de ambos os autores aponta, desta forma, para a inexistência do forjamento de relações paternalísticas, entre senhor e escravo, através do batismo, isto por causa do evidente antagonismo entre propriedade escrava e compadrio. Esta tese é reiteradamente reforçada por Stuart Schwartz em outros trabalhos de sua autoria, nos quais nega, sempre novamente, o apadrinhamento dos escravos por seus próprios senhores no século XVIII: “O paternalismo não se expressava usualmente na forma de laços de compadrio. Em vez disso, o padrão dominante parece ter sido a escolha de um homem branco que pudesse interceder junto ao proprietário em caso de dificuldades futuras." 26

Ainda assim, apesar de hipótese de ocorrência muito rara, tanto Stephen Gudeman quanto Stuart Schwartz não descartam, uma vez por todas, a possibilidade da existência de um paternalismo indireto do compadrio, por meio do apadrinhamento das crianças cativas por proprietários de outros escravos ou por pessoas de certa forma ligadas ao próprio senhor. ${ }^{27}$

Após a refutação da tese paternalista, as pesquisas historiográficas mais recentes começam a atentar para a problemática da existência ou inexistência das relações de paternalismo direto ou indireto nas alianças estabelecidas na pia batismal pelos escravos, como se verá adiante.

\subsection{SIGNIFICADO AMBIVALENTE DO COMPADRIO: SOLIDARIEDADE OU DOMINAÇÃO?}

${ }^{25}$ SCHWARTZ, Stuart B. Segredos internos: engenhos e escravos na sociedade colonial, 1550-1835. São Paulo: Companhia das Letras, 1988, p. 331.

\footnotetext{
${ }^{26}$ Ibidem, p. 67.

${ }^{27}$ GUDEMAN; SCHWARTZ, op. cit., p. 44-45.
} 
Quais seriam, afinal de contas, os reflexos do estabelecimento destas relações de compadrio, seja na direção vertical seja na direção horizontal, para a vida dos escravos? Haveria alguma estratégia subjacente à opção dos padrinhos? Se, como se indicou até agora, o batizado engendrava significados que transbordavam o universo religioso, a conclusão preliminar da historiografia recente aponta para uma resposta afirmativa.

Neste sentido, quando Stephen Gudeman e Stuart Schwartz tentam encontrar uma possível explicação para a tendência predominante da escolha de padrinhos livres para crianças escravas, os autores deduzem a motivação do próprio significado que o instituto do compadrio possuía naquela sociedade. Neste sentido, vale retomar novamente que

Segundo a doutrina e as práticas da Igreja Católica, o papel dos padrinhos era vital para a formação da criança. Os laços entre afilhado e os padrinhos eram tão fortes quanto entre o filho e os pais. Paralelamente, o conjunto de laços entre pais e padrinhos estabelecia obrigações e dependências mútuas. [...] Não é, pois, surpreendente encontrar um percentual elevadíssimo de brancos como padrinhos nos batizados examinados. Não eram só os pais brancos que escolhiam um padrinho branco, mas também os índios e africanos. ${ }^{28}$

Assim, os escravos deviam buscar - e há evidências na história de que efetivamente buscaram - por um possível aliado ou protetor através do compadrio. Não devemos esquecer que possuir "[...] um padrinho livre residindo na vizinhança representava vantagens para os escravos, vantagens de maior peso que aquelas propiciadas por amizades íntimas ou por laços de família que levariam à escolha de outros escravos." 29

Se, por outro lado, estes historiadores negam um significado paternalista inscrito nas relações espirituais nascidas do batismo, ao menos em tendência, então o compadrio entre livres e escravos parece refletir um sentido mesmo de aliança e

\footnotetext{
${ }^{28}$ SCHWARTZ. Segredos..., p. 66.

${ }^{29}$ GUDEMAN; SCHWARTZ, op. cit., p. 47.
} 
solidariedade. É claro, tal afirmação não deve ser idealizada, pois se é possível inferir que se estabeleciam relações solidárias entre livres e escravos, isto não significa dizer que o compadrio nivelava por completo as diferenças entre pessoas de qualidades diferentes, segundo a lógica daquela sociedade escravocrata, que se fundamentava juridicamente, como bem nos lembra Keila Grinberg, na distinção entre pessoas e coisas, ou seja, livres e escravos. ${ }^{30}$

No que diz respeito às inferências feitas por Manolo Florentino e José Roberto Góes sobre a predominância das relações horizontais no apadrinhamento de crianças cativas, faz-se necessário, em um primeiro momento, contextualizar a sua pesquisa.

Partem os autores da tese que na sociedade escravista da América Portuguesa a inserção constante de estrangeiros no cativeiro - por força da reposição ou ampliação da mão de obra escrava - gerava um clima generalizado de guerra na senzala, por causa da junção forçada de individualidades diferentes. Neste contexto, é imperioso ressaltar que o conceito de escravo não rotulava pessoas homogêneas, mas seres humanos das mais diversas culturas - com frequência não falavam nem a mesma língua -, para as quais a convivência era difícil. ${ }^{31}$

O que motivaria, portanto, segundo os autores, o padrão de escolha dos padrinhos daquela localidade seria a pretensão de alcançar a paz na senzala através da criação de laços de proteção e ajuda recíproca entre os cohabitantes do cativeiro, já que em relação aos escravos "devia se lhes afigurar vital construir laços de solidariedade e de auxílio mútuo que os ajudassem a sobreviver no cativeiro - a levar a vida" $^{32}$. Os autores sugerem que quanto maior era o cativeiro, maior era também o grau de conflito e, por consequência, a necessidade de estabelecer vínculos de solidariedade dentro do grupo. Deste modo, quanto maior o tamanho do plantel, maior sua proximidade com o parentesco. Para os historiadores, "[a] relação diretamente proporcional entre tamanho de plantel e parentesco constitui-se em mais uma

\footnotetext{
${ }^{30}$ GRINBERG, op. cit. p. 47.

${ }^{31}$ FLORENTINO; GÓES, op. cit., p. 32-37.

${ }^{32}$ Ibidem, p. 36.
} 
indicação de que as famílias escravas tinham por sentido fundamental o estabelecimento da paz.",33

Além dos laços forjados dentro da senzala, os cativos também procuravam laços de parentesco espiritual fora dela, o que indica certa abertura da família escrava, com evidente significação política. Assim, os escravos tentavam ampliar o raio social das alianças políticas e sociais, através do compadrio inclusive com ex-escravos, escravos pertencentes a outros senhores e, em casos eventuais, com alguns proprietários de cativos. ${ }^{34}$

Deste modo, carrega o compadrio, igualmente na pesquisa desses autores, uma significação de solidariedade estabelecida entre os compadres e suas famílias. Porém, chamam eles atenção para um elemento muito interessante: se as pessoas reunidas na senzala não se compreendiam como um "nós" e se em decorrência do ambiente hostil buscavam, através de laços familiares, gerar alianças estratégicas que facilitassem a sobrevivência no cativeiro, então as relações familiares implicavam o sentido de solidariedade para os escravos, mas ao mesmo tempo também criavam e reforçavam a sua posição de escravo. Isto porque, em primeiro lugar, a pacificação na senzala facilitava a dominação do contingente escravo pelo senhor, e, em segundo lugar, porque a construção de uma comunidade no interior das senzalas através das alianças familiares fazia nascer um grupo de pessoas que começava a se identificar como iguais, isto é, como escravos. ${ }^{35}$

Os autores percebem este fenômeno como cíclico e o descrevem da seguinte forma:

Não é suficiente apresar um homem para se possuir um cativo - é preciso torná-lo escravo. No Brasil, o processo de produção social deste tipo específico de trabalhador iniciava-o o mercado, pela introdução do estrangeiro, e concluía-o o próprio escravo, tornado africano e brasileiro, membro de uma comunidade, de um

\footnotetext{
${ }^{33}$ Ibidem, p. 95.

${ }^{34}$ Ibidem, p. 90.

${ }^{35}$ Ibidem, p. 35-37.
} 
nós cativo. Apenas assim, era possível ao senhor auferir uma renda política sem a qual o seu retorno ao mercado estaria comprometido. ${ }^{36}$

Ou seja, paradoxalmente o compadrio estabeleceria então tanto um significado de solidariedade quanto de dominação, pois o "cativeiro era estruturalmente dependente do parentesco cativo." 37

\section{ALGUNS ESTUDOS DE CASOS: O COMPADRIO NA REGIÃO DO PARANÁ NA PASSAGEM DO SÉCULO XVIII PARA O XIX}

A seguir, serão apresentadas as análises de alguns estudos de casos para a localidade da região hoje abrangida pelo Estado do Paraná, com o intuito de verificar até que ponto é possível verificar algumas das tendências identificadas pela historiografia recente para este espaço geográfico, já que, como se colocou no início deste trabalho, muitas vezes não é possível generalizar certos aspectos para todo o território brasileiro sem incorrer em grave equívoco metodológico.

\subsection{SÃO JOSÉ DOS PINHAIS}

As tendências afirmadas pela historiografia recente também são discutidas por Cacilda Machado para as relações de compadrio de escravos da região de São José dos Pinhais, na transição entre o século XVIII e XIX, com o intuito de acrescentar novos aspectos ao conhecimento histórico existente. A região se caracterizava pela exploração da pecuária e da agricultura de subsistência e pelo abastecimento do

\footnotetext{
${ }^{36}$ Ibidem, p. 37.

${ }^{37}$ Ibidem, loc. cit.
} 
mercado interno. De modo peculiar, sua população era constituída por mais ou menos $40 \%$ de pardos. O percentual de escravos varia, no período abrangido, entre $15 \%$ e $10 \%$ da população. Predominam nesta região as pequenas escravarias; os escravos pertenciam a poucos senhores, e os senhores possuíam em média no máximo 4 escravos. Outro dado importante para a análise da autora é o perfil sexo-etário da população escrava, que era semelhante a da população livre, o que indica o abastecimento escravo endógeno, quer dizer, a mão de obra escrava não se buscava em princípio no mercado de almas, mas pela reposição natural dos cativos da região. ${ }^{38}$

No que diz respeito à tese de Stephen Gudeman e Stuart Schwartz, de questionar o uso do compadrio para o reforço de relações paternalistas entre os senhores e seus próprios escravos, a autora pondera que o parentesco do padrinho do escravo é muito raramente revelado em estudos baseados apenas em registros de batismo. ${ }^{39}$ Com base em sua análise em diversas fontes, verifica laços entre o escravo e seu proprietário, bem como a predominância de laços de compadrio com pessoas livres. Os casos estudados pela autora permitem, no entanto, identificar que de fato era muito difícil o senhor - ou os prováveis herdeiros dos cativos (filho e genro) - batizar o próprio escravo. Há com maior frequência outros vínculos parentais, não de paternalismo direto, mas indireto, isto é, o apadrinhamento por sobrinhos, irmãos, cunhados e parentes mais distantes do senhor do cativo. Deste modo, a autora concorda com a incompatibilidade dos idiomas da propriedade escrava e o batismo, mas salienta que se deve relativizar a questão da inexistência do uso do compadrio para reforçar as relações paternalistas, pois há de se admitir ao menos certo grau de controle senhorial sobre a socialização dos seus escravos, com base nas recorrentes ligações de compadrio dos cativos desta região com parentes do senhor - e isto vale tanto para casais de escravos e casais mistos (livre e escravo). ${ }^{40}$

${ }^{38}$ MACHADO, Cacilda. As muitas faces do compadrio de escravos: o caso da Freguesia de São José dos Pinhais (PR) na passagem do século XVIII para o XIX. Revista Brasileira de História, v. 26, p. 51-54, 2006.

\footnotetext{
${ }^{39}$ Ibidem, p. 69.

${ }^{40}$ Ibidem, p. 67-69.
} 
Em relação à pergunta sobre quem escolhia os padrinhos, a despeito da existência do elemento do controle senhorial (paternalismo indireto), a autora supõe que tal não levasse à anulação de qualquer iniciativa escrava, pois alguns membros da família senhorial nunca foram chamados para apadrinhar escravos, muitas vezes os escravos se tornavam compadres de pessoas com parentesco muito distante do proprietário dos pais da criança batizada, e muitos estabeleceram vínculos com pessoas não aparentadas com seus proprietários, até mesmo da elite, inclusive de outras vilas. Tais casos podem sugerir que não importava apenas a estratégia de intermediação de um livre nos conflitos com o senhor, ou a viabilização da comunidade de cativos, mas que havia na escolha uma valorização de antigos laços sociais e afetivos, já que os padrinhos por vezes viajavam de longe para batizar os escravos. A par do elemento de dominação, é inegável, deste modo, o evidente significado de solidariedade do compadrio, no sentido de que a constituição de alianças com homens livres seria valioso nessa sociedade hierarquizada, onde escravos, forros e livres de cor eram pessoas com "menor qualidade". Para a autora, também o elemento da idade dos padrinhos escolhidos indica a participação dos escravos na escolha do padrinho, já que muitos deles tinham menos de 25 anos de idade, o que pode indicar a preocupação dos escravos em assegurar a proteção de sua prole por muito tempo de sua vida, ao menos até poderem estabelecer seus próprios laços de aliança. ${ }^{41}$

Apesar da importância estratégica do compadrio com parentes de seus senhores e da elite branca, os escravos nunca deixaram de se relacionar com outros escravos, forros e livres de cor ou brancos pobres. ${ }^{42}$ Desta forma, as fontes estudadas pela autora confirmam as teses dos mais recentes estudos de que o compadrio era uma aliança usada de diversas maneiras por escravos e libertos. Por um lado, "foi um instrumento efetivo na formação e consolidação de uma comunidade de escravos e livres de cor, mas também ligava essa população com a sociedade branca de todos os

\footnotetext{
${ }^{41}$ Ibidem, p. 70-72.

${ }^{42}$ Ibidem, p. 72.
} 
estratos sociais, e ao menos em São José dos Pinhais, com a parentela senhorial."43 Constatam-se, portanto, tanto as relações nos eixos horizontal e vertical.

Em relação ao apadrinhamento por membros da parentela senhorial a autora afirma que, por um lado, era uma aliança que sacramentava a paz, mas, por outro lado, era uma aliança de proteção e a permissão de convivência e comunicação com a escravaria. Ou seja, apesar do elemento paternalista imbricado nestas relações de compadrio, talvez o parentesco fictício com senhores de outros escravos poderia ter sido usado para aproximar-se das casas em que parentes e amigos dos escravos compadres viviam como cativos ou agregados. Neste sentido, "constituir alianças com escravistas e com a parentela do senhor seria um outro caminho para a viabilização de uma comunidade de cativos nessa freguesia de predomínio de pequenas escravarias."44

Assim, também Cacilda Machado afirma a ambivalência do compadrio escravo no sentido de que, por um lado, o parentesco espiritual com pessoas de status superior pudesse ter funcionado como proteção social e ampliação de uma comunidade de negros e pardos, mas por outro lado acabou reforçando ou talvez até mesmo criando, um significado de dominação na relação de compadrio, levando em última análise à debilitação do caráter igualitário que era implícito do parentesco espiritual. ${ }^{45}$

\subsection{CURITIBA}

A região de Curitiba, em conformidade com a tendência das demais localidades paranaenses da época, caracteriza-se por uma pequena quantidade de famílias, funcionando como unidades produtivas autossuficientes, cuja atividade básica era a agricultura de subsistência e a criação de gado durante todo o século

\footnotetext{
${ }^{43}$ Ibidem, p. 73.

${ }^{44}$ Ibidem, p. 74.

${ }^{45}$ Ibidem, loc. cit.
} 
XVIII. A partir do impulso do tropeirismo, no século XIX, surge até mesmo o início de pequenos comércios justamente nas regiões por onde passavam os homens que conduziam gado para a feira de Sorocaba. ${ }^{46}$

No que diz respeito à população escrava, no planalto curitibano, um quinto dos habitantes era escrava, nos anos de 1798-1839. Em Curitiba mesmo, a porcentagem dos escravos nunca passou de $25 \%$ da população. Assim como indicado por Cacilda Machado para São José dos Pinhais, também aqui a população escrava se caracterizava pela reprodução natural, pelo equilíbrio dos sexos e o alto índice de crianças, principalmente em planteis com mais de 15 cativos. Os proprietários de escravos eram em geral pequenos proprietários de terras e $70 \%$ dos senhores de Curitiba possuíam entre 1 a 5 escravos. Ainda que os números absolutos apontem para uma quantidade pequena de escravos, sua concentração na mão de poucos senhores e a grande quantidade de pequenos proprietários indicam para Dejalma Esteves de Ávila Junior que em Curitiba havia uma sociedade escravista. ${ }^{47}$

Para se pensar as relações de compadrio de cativos nesta região, o estudo referencial há de ser o trabalho coordenado por Stuart Schwartz intitulado "Escravos, roceiros e rebeldes". Em um dos capítulos desta obra, o autor identifica para Curitiba os mesmos padrões de escolha de padrinhos afirmados em suas conclusões preliminares sobre o compadrio de cativos para o Recôncavo baiano. Neste povoado paranaense verificou do mesmo modo a predominância estatística de padrinhos livres para as crianças cativas. Os dados colhidos nos 504 assentos batismais da paróquia curitibana, no espaço temporal entre 1800 e 1869, indicam as seguintes tendências na escolha dos padrinhos: $70 \%$ das crianças tinham um par de padrinhos livres e pouco menos de 20\% das crianças tiveram um par de padrinhos escravos. É interessante notar que quando os padrinhos eram de estatus social desigual, a predominância era de

46 ÁVILA JUNIOR, Dejalma Esteves de. Compadrio escravo em Curitiba: um estudo das relações sociais estabelecidas pelos escravos da Freguesia de Nossa Senhora da Luz dos Pinhais de Curitiba (1790 - 1834). Monografia de conclusão de curso em História Setor de Ciências Humanas, Letras e Artes, Universidade Federal do Paraná, Curitiba, 2003, p. 16-18.

${ }^{47}$ Ibidem, p. 18-19. 
madrinha escrava e padrinho livre, talvez tendo em vista o padrinho como protetor futuro da criança e a madrinha como mãe substituta em caso de morte prematura da mãe biológica. Também vale ressaltar que na hipótese de padrinhos escravos, estes geralmente eram de outras escravarias, possivelmente em decorrência dos planteis pequenos na região de Curitiba. ${ }^{48}$

Em trabalho monográfico, Dejalma Esteves de Ávila Junior, tendo como base as obras paradigmáticas de José Roberto Góes e Stuart Schwartz, procura verificar os pesos relativos entre os eixos vertical e horizontal para o espaço geográfico de Curitiba na primeira metade do século XIX. Para levar a efeito a sua proposta, analisou os registros paroquiais de batismo da Catedral Basílica Menor de Curitiba, nos períodos de 1790-1814, 1820-1824, e 1830-1834. ${ }^{49}$ Em sua pesquisa, diferencia entre o apadrinhamento de crianças escravas e de adultos escravos, sendo que os dados coletados permitem conclusões preponderantemente para as crianças. ${ }^{50}$

No que diz respeito ao perfil dos padrinhos destas crianças escravas, seu estudo confirma as afirmações de Stuart Schwartz para Curitiba, isto é, a maioria dos padrinhos de escravos eram livres, sendo que, entre eles, os senhores raramente eram padrinhos de seus próprios escravos. No entanto, para o período de 1790 a 1804, o cruzamento dos dados da lista nominativa com os registros de batismo revelou que $37,4 \%$ dos padrinhos livres eram senhores de escravos ou filhos de senhores de cativos, sugerindo a possibilidade de certo paternalismo indireto nas relações de parentesco espiritual. Às vezes, eram pessoas de posição social ainda superior ao proprietário da criança escrava, o que parece indicar certa proximidade entre livres e escravos, o topo e a base da pirâmide social naquela localidade. ${ }^{51}$

Por outro lado, a porcentagem de padrinhos escravos para todo o espaço temporal pesquisado (1790-1814, 1820-1824, e 1830-1834) foi, em média, de 23,5\%.

\footnotetext{
${ }^{48}$ SCHWARTZ, Stuart B. Escravos, roceiros e rebeldes. Bauru: Edusc, 2001, p. 223-225.

${ }^{49}$ ÁVILA JUNIOR, op. cit., p. 11.

${ }^{50}$ Ibidem, p. 13.

${ }^{51}$ Ibidem, p. 31.
} 
Para avaliar o peso deste número, o autor procura compará-lo com a porcentagem da população escrava da região para esta época. Os Mapas de Habitantes da CapitaniaProvínica de São Paulo mostram que, nos anos de 1804, 1824 e 1830, a população escrava da região de Curitiba ficava em torno de $20 \%$, nunca superior a $25 \%$. A partir desta confrontação de informações, conclui que, ainda que os padrinhos livres correspondessem à maioria dos casos, os escravos buscavam preferencialmente padrinhos da mesma condição jurídica, já que o confronto dos dados estatísticos evidencia uma sobrerrepresentação dos escravos no compadrio das crianças cativas. ${ }^{52}$

Em Curitiba a maior parte dos plantéis contava com menos de 6 escravos. Deste modo, como provavelmente era difícil encontrar padrinhos no mesmo plantel, a tendência era buscar os padrinhos fora do próprio cativeiro, seja pessoa livre ou seja escravo. Nas hipóteses de padrinhos escravos, verificam-se 73,4\% de padrinho escravo de plantel diferente e em torno de $68 \%$ de madrinha escrava de plantel diferente da criança. É interessante notar que mesmo nos grandes planteis de Curitiba, a maioria dos padrinhos escravos era de escravaria diferente, o que demonstra certa coesão da comunidade cativa nesta região e a busca pela solidificação de relações entre iguais. Por outro lado, o tamanho reduzido dos planteis deveria ter facilitado o contato com pessoas livres, o que, conjugado com a dificuldade de encontrar padrinhos da mesma condição jurídica, justificaria a tendência maior de procurar por padrinhos livres. ${ }^{53}$

Sobre a tese da pacificação da senzala através das relações de compadrio, indicada por Manolo Florentino e José Roberto Góes, o autor sugere que nesta região provavelmente não se aplicaria, tendo em vista as características da população escrava da localidade, marcada por uma reposição natural da mão de obra escrava, em decorrência das características populacionais de idade, sexo etc. ${ }^{54}$ Não haveria então a inserção constante de forasteiros no cativeiro.

Assim, os dados colhidos na pesquisa indicam que os padrões de escolha dos

\footnotetext{
${ }^{52}$ Ibidem, p. 21.

${ }^{53}$ Ibidem, p. 23-26.

${ }^{54}$ Ibidem, p. 27.
} 
padrinhos de crianças cativas interagiram na região. Há nos laços de compadrio de crianças cativas tanto uma manifesta verticalidade, demonstrada pela maioria numérica dos padrinhos livres - entre eles muitos senhores de cativos ou membros da parentela senhorial -, quanto uma forte horizontalidade, dedutível a partir da sobrerrepresentação proporcional dos escravos na função de padrinho. É possível ainda inferir elementos de dominação - paternalismo indireto - e componentes de solidariedade - comunidade cativa coesa e proximidade com os livres nos pequenos planteis - nas relações de parentesco espiritual dos cativos. Neste sentido, o autor conclui que o compadrio em Curitiba era complexo, havendo a interação constante dos conceitos de verticalidade/horizontalidade e dominação/solidariedade, possibilitando a homogeneização da comunidade cativa e sua aproximação do mundo dos livres. ${ }^{55}$

\section{CONSIDERAÇÕES FINAIS}

Os estudos de caso, delimitados geograficamente ao espaço hoje compreendido pelo Estado do Paraná, evidenciaram claramente a impossibilidade de assumir, sem reflexão e comprovação, afirmações genéricas para todo o território brasileiro. Algumas tendências apontadas pela historiografia mais recente sobre o compadrio de cativos se confirmaram nesta região - por exemplo, a predominância de padrinhos livres para a criança escrava -, ao passo que isto não ocorreu com algumas outras tendências - como foi o caso da utilização do compadrio para estabelecer a paz nas senzalas.

Por outro lado, cristalizou-se também a importância de verificar a coerência de certas ideias com o auxílio de fontes primárias, pois se até algum tempo os historiadores apontavam o escravo como mero objeto, incapaz de atitudes próprias, como simples produto de relações verticais de poder, certamente por dedução lógica

\footnotetext{
${ }^{55}$ Ibidem, p. 38.
} 
de sua condição jurídica como "coisa", as pesquisas fundamentadas, em especial, nos registros paroquiais de batismo revelam a manutenção de laços sociais tanto na direção vertical quanto horizontal.

Significa dizer: projetar a partir da condição jurídica dos escravos, classificados pela doutrina como "bem semovente", sua posição como sujeito passivo, sem interferência nas relações sociais ou sem contribuição para a manutenção da escravidão, não é possível. Como bem lembra Kátia M. de Queirós Mattoso, no Brasil dos séculos XVII, XVIII e XIX, as relações sociais são muito mais complexas que a mera oposição entre dominantes e dominados, isto é, homens livres versus escravos, pois há níveis de hierarquia social tanto na classe dos dominantes quanto dos dominados. ${ }^{56}$ Esta condição ambígua do escravo se projeta para as relações de compadrio que contêm em seu bojo tanto características de solidariedade quanto de dominação.

O escravo não era aqui um mero objeto dominado, ${ }^{57}$ mas parece ter exercido um papel ativo nas relações sociais, na tentativa de superar as contradições entre o mundo dos homens livres e dos escravos. Para tanto, os dados históricos sugerem que ele buscou todo tipo de solidariedade, com as pessoas das mais diversas classes sociais. As pesquisas realizadas no Paraná indicam, além disso, que senhores e escravos poderiam estar mais próximos do se pensava até então, ${ }^{58}$ provavelmente em

\footnotetext{
${ }^{56}$ MATTOSO, Kátia M. de Queirós. Ser escravo no Brasil. São Paulo: Brasiliense, 2003, p.
}

${ }^{57}$ Neste contexto, deve-se ter em mente sempre a advertência metodológica do filósofo Hilary Putnam no sentido de abandonar as diversas dicotomias, tão difundidas no mundo contemporâneo, já que a realidade é muito mais complexa do que a distinção entre fato e valor, objetivo e subjetivo etc., ou neste caso a dicotomia entre dominado e dominador. (PUTNAM, Hilary. Razão, verdade e história. Lisboa: Dom Quixote, 1992).

${ }^{58}$ A pretensão deste artigo é mostrar que a condição do escravo não consistia apenas em dominação, pois se assim fosse, a escravidão não teria sido capaz de se manter por tanto tempo no seio social. Contudo, não se está querendo romantizar a relação entre senhor e escravo, pois isto significaria cair no extremo oposto. Ainda que existiram momentos de aproximação e verdadeiros laços de solidariedade entre senhores e escravos, isto não anulava de forma alguma o princípio fundante da sociedade escravista, ou seja, a diferença entre escravo e pessoa livre. (Compare neste sentido também NOVAIS, Fernando A. Condições da privacidade na colônia. In: História da vida privada no Brasil: cotidiano e vida privada na América Portuguesa. São Paulo: Companhia das Letras, 1997. p. 29.). 
decorrência do tamanho dos planteis, que eram muito pequenos nessa região. Também a coesão da comunidade cativa local sugere uma atitude pró-ativa por parte dos escravos, no sentido de estabelecer alianças com pessoas da mesma condição social e de construir uma identidade comum.

O estudo das relações de compadrio de escravos revela, portanto, que paradoxalmente - a atitude dos cativos parece ter contribuído para a manutenção do sistema jurídico-político escravista no Brasil por mais de três séculos: de um lado, os cativos se criavam e recriavam como escravos, através da construção de uma identidade cativa comum; por outro lado, assimilaram a lógica da "economia política dos favores", com o intuito de melhorar as suas condições de vida, pagando, no entanto, o preço político de reforçar os seus vínculos de dependência instituídos por esta sociedade escravista.

\section{REFERÊNCIAS}

ANDREAZZA, Maria Luiza. Dominium, terras e vassalagem na América Portuguesa. In: SILVA, Luiz Geraldo (org.). Facetas do Império na História: conceitos e métodos. São Paulo: Hucitec, 2008. p. 271-285.

ÁVILA JUNIOR, Dejalma Esteves de. Compadrio escravo em Curitiba: um estudo das relações sociais estabelecidas pelos escravos da Freguesia de Nossa Senhora da Luz dos Pinhais de Curitiba (1790 - 1834). Monografia de conclusão de curso em História Setor de Ciências Humanas, Letras e Artes, Universidade Federal do Paraná, Curitiba, 2003.

BICALHO, Maria Fernanda Baptista. As câmaras ultramarinas e o governo do Império. In: FRAGOSO, João (org.). O antigo regime nos trópicos: a dinâmica imperial portuguesa (séculos XVI-XVIII). Rio de Janeiro: Civilização Brasileira, 2001. p. $189-221$.

BRÜGGER, Silvia Maria Jardim. Compadrio e escravidão: uma análise do apadrinhamento de cativos em São João Del Rei, 1730-1850. In: XIV ENCONTRO NACIONAL DE ESTUDOS POPULACIONAIS, 2004, Caxambú. Anais do XIV 
Encontro Nacional de Estudos Populacionais. Caxambu: ABEP, 2004. Disponível em: http://www.abep.nepo.unicamp.br/site_eventos_abep/PDF/ABEP2004_119.pdf.

Acesso em: 03 ago. 2009.

FLORENTINO, Manolo; GÓES, José Roberto. A paz das senzalas: famílias escravas e tráfico atlântico. Rio de Janeiro: Civilização Brasileira, 1997.

GRINBERG, Keila. Código Civil e cidadania. Rio de Janeiro: Jorge Zahar, 2001.

GUDEMAN, Stephen; SCHWARTZ, Stuart. Purgando o pecado original: compadrio e batismo de escravos na Bahia no século XVIII. In: REIS, João José (org). Escravidão e invenção da liberdade: estudos sobre o negro no Brasil. São Paulo: Brasiliense, 1988.

HAMEISTER, Martha Daisson. Na pia batismal: estratégias de interação, inserção e exclusão social entre os migrantes açorianos e a população estabelecida na vila de Rio Grande, através do estudo das relações de compadrio e parentescos fictícios (17381763). In: V CONGRESSO BRASILEIRO DE HISTÓRIA ECONÔMICA E $6^{\mathrm{a}}$ CONFERÊNCIA INTERNACIONAL DE HISTÓRIA DE EMPRESAS - 10 anos de ABPHE, 2003. Disponível em: http://www.abphe.org.br/congresso2003/Textos/Abphe_2003_91.pdf. Acesso em: 03 ago. 2009.

MACHADO, Cacilda. As muitas faces do compadrio de escravos: o caso da Freguesia de São José dos Pinhais (PR) na passagem do século XVIII para o XIX. Revista Brasileira de História, v. 26, p. 49-77, 2006.

MATTOSO, Kátia M. de Queirós. Ser escravo no Brasil. São Paulo: Brasiliense, 2003.

NOVAIS, Fernando A. Condições da privacidade na colônia. In: História da vida privada no Brasil: cotidiano e vida privada na América Portuguesa. São Paulo: Companhia das Letras, 1997. p. 13-39.

PUTNAM, Hilary. Razão, verdade e história. Lisboa: Dom Quixote, 1992.

QUIRINO, Gisele Dias. Compadres e comadres: um estudo sobre o prestigio social dos parentes rituais (Porto Feliz, São Paulo, século XIX). In: XIII ENCONTRO DE HISTÓRIA ANPUH-RIO IDENTIDADES, 2008, Seropédica. Anais do XIII Encontro de História Anpuh-Rio Identidades, 2008. Disponível em: http://encontro2008.rj.anpuh.org/resources/content/anais/1212946675 ARQUIVO tex togisele.pdf. Acesso em: 03 ago. 2009. 
SCHWARTZ, Stuart B. Escravos, roceiros e rebeldes. Bauru: Edusc, 2001.

Segredos internos: engenhos e escravos na sociedade colonial, 1550-1835. São Paulo: Companhia das Letras, 1988.

VENÂNCIO, Renato Pinto; SOUZA, Maria José Ferro de; PEREIRA, Maria Teresa Gonçalves. O compadre Governador: redes de compadrio em Vila Rica de fins do século XVIII. Revista Brasileira de História, v. 26, p. 273-294, 2006. 